\title{
A COMPETÊNCIA COMUNICATIVA EM LE AMPLIADA PELA TEORIA FUNCIONALISTA DE TRADUÇÃO: UMA PROPOSTA DIDÁTICA
}

\section{A DIDACTIC PROPOSAL FOR COMMUNICATIVE COMPETENCE IN FOREIGN LANGUAGE EXPANDED BY THE FUNCTIONALIST TRANSLATION THEORY}

\author{
Maria José Laiño' \\ Camila Teixeira Saldanha²
}

\begin{abstract}
RESUMO: O presente trabalho pretende apresentar uma sugestăo de sequência didática (SD), na qual sâo abordadas atividades em torno do gênero discursivo tirinhas, com o intuito de preparar os alunos participantes da pesquisa à elaboraçăo de uma atividade tradutória de algumas tiras da Mafalda. Inspirada pelos pressupostos teóricos de Dolz, Noverraz e Schneuwly (2004), a SD está composta por sete etapas, aplicadas aos alunos de graduaçáo de um Curso de Letras - Português e Espanhol - de uma universidade federal, em 2015.1. O marco teórico que dá suporte à SD está ancorado nos preceitos funcionalistas de traduçăo, elucidados por Nord (2010), nos quais elementos como o destinatário, o contexto sociocultural e o gênero discursivo envolvido sâo importantes para que o tradutor/aluno seja capaz de otimizar seu processo tradutório e elaborar uma traduçâo funcionalista. Com esta proposta de trabalho, o escopo se volta ao uso da traduçâo pedagógica em sala de aula, isto é, ao uso de atividades tradutórias com o objetivo de auxiliar o desenvolvimento das habilidades que compôem o aprendizado de uma língua estrangeira. Ao longo da SD, os estudantes partícipes relataram que puderam revisitar e ampliar seus conceitos de traduçăo, uma vez que estavam influenciados pelo Método Gramática e Traduçâo.
\end{abstract}

Palavras-chave: gêneros discursivos; ensino de línguas; traduçâo pedagógica; funcionalismo.

ABSTRACT: This paper aims to present a learning and teaching sequence (LTS) of activities that approach the comic strip genre. These activities prepare students, who take part of the research, to produce a translation activity from some of Mafalda's comic strips. It was applied to undergraduate students of a Portuguese-Spanish Language course at a Brazilian federal university in the first semester of 2015. According to the theoretical basis of Dolz, Noverraz and Schneuwly (2004), the LTS is structured in seven steps. The LTS is also based on the functionalist translation

Doutora em Estudos da Traduçâo. Professora de língua espanhola e linguística aplicada da Universidade Federal da Fronteira Sul. E-mail: lainoreales@gmail.com

Mestre em Estudos da Traduçâo. Professora de língua espanhola e linguística aplicada da Universidade Federal de Santa Catarina. E-mail: cami.saldanha@gmail.com 
theory (Nord, 2010) in which the addressee, the socio-cultural context and the genre are important elements for the student/translator to be able to optimize the translation process and perform a functional translation. The scope of this working proposal is to use pedagogical translation in class, which means translation activities in order to help students develop abilities that are part of the process of learning a foreign language. During the LTS, the students reported that they could revisit and increase their translation concepts since they had been influenced by the grammartranslation method.

Keywords: speech genres, language teaching, pedagogical translation, functionalism.

\section{INTRODUÇÃO}

Enquanto docentes de língua espanhola e formadoras de futuros professores, temos conhecimento de que, historicamente, o conceito de língua tem sido definido sob a ótica de perspectivas distintas. Isso significa que ora seu foco está relacionado à estrutura da língua, ora com ênfase na comunicaçăo, ora com ênfase na interaçăo entre os pares (interlocutores), entre outros enfoques.

Levando em conta a diversidade de conceitos sobre língua, é válido explicar que nossas bases teóricas estăo calcadas nos pressupostos bakhtinianos, ao entender a língua como um sistema de comunicaçăo que está condicionado ao contexto sócio -histórico-cultural dos sujeitos. Isso implica que normas, questóes gramaticais e estruturais săo elementos que fazem parte desse sistema de comunicaçâo, mas náo assumem papel central em nosso conceito de língua, pois como bem explicita Bakhtin (2010a, p. 96):

o que importa năo é o aspecto da forma linguística que, em qualquer caso em que esta é utilizada, permanece sempre idêntico. Năo, para o locutor o que importa é aquilo que permite que a forma linguística figure num dado contexto, aquilo que a torna um signo adequado às condiçóes de uma situaçáo concreta dada. Para o locutor, a forma linguística năo tem importância enquanto sinal estável e flexível.

Através dos preceitos de Bakhtin, percebemos que o conceito de língua que nos norteia está intimamente ligado ao sujeito, uma vez que, por mais que haja normas de uso de uma língua, esta está suscetível a mudanças de acordo com as necessidades comunicativas dos interlocutores.

Além de defendermos a perspectiva da linguagem como prática social, partimos do ponto de vista da traduçâo em sala de aula segundo a ótica funcionalista, como uma ferramenta que acrescenta elementos positivos para o aprendizado do novo idioma, mas principalmente para a competência comunicativa (CC) do aluno em língua estrangeira (LE).

Para melhor ilustrar nossos posicionamentos teóricos, apresentamos uma sequência didática (SD) elaborada com base em uma atividade tradutória do gênero tirinha, com o objetivo de auxiliar o desenvolvimento da CC dos estudantes envolvidos. A SD, detalhada mais adiante, foi aplicada às quatro alunas matriculadas na disciplina "Estudos Avançados em Língua Espanhola I: prática de textos", no mês de abril de 2015. A referida disciplina faz parte da grade curricular de um curso de graduaçáo em Letras: 
Português e Espanhol de uma universidade federal brasileira. A atividade proposta tem como pano de fundo a teoria funcionalista de traduçâo de Christiane Nord (2010), para a qual alguns elementos săo determinantes no processo tradutório, dentre os quais destacamos o destinatário, o contexto situacional e a análise textual.

Neste artigo apresentamos um breve histórico teórico de Vygotsky e Bakhtin sobre abordagem e dialogismo, a fim de contextualizar nosso conceito de língua, construçâo de conhecimento e práticas sociais. Logo, partimos para o conceito de competência comunicativa e trazemos o enlace entre a traduçấo e o ambiente escolar. Por fim, mostramos todos os passos da SD e a discussáo dos dados provenientes do processo tradutório.

\section{ABORDAGEM SOCIOINTERACIONISTA}

Para Vygotsky (1998), um dos pontos chave de sua teoria sociointeracionista é a de que a educaçăo tem sua origem na sociedade e na cultura e é mediada pela linguagem que age entre o individual e o social. Corroborando essa ideia, Saldanha (2011) ressalta que, na teoria vygotskiana, o indivíduo constrói o seu conhecimento através de suas interaçóes e a construçấo dos significados se dá por meio de um processo social, por meio da troca entre os indivíduos, criando um conhecimento socialmente construído. Através das relaçōes que os indivíduos estabelecem entre si é que se constroem diferentes significados de mundo, ampliando a visâo que temos de nós mesmos, ou seja, o 'eu' se constrói a partir do 'outro'.

Nas palavras de Conteratto (2005, p. 20), Vygotsky considera que:

no sociointeracionismo, a linguagem é vista como forma de interaçăo humana e matéria-prima para a emergência da consciência; é a linguagem que possibilita ao homem apreender o mundo e posicionar-se criticamente perante os outros. Por outro lado, sâo as atividades sociais e históricas dos homens que geram a linguagem, ou seja, é no espaço social que a linguagem garante sua própria existência e significaçăo.

Para o sociointeracionismo, o crescimento intelectual dos aprendizes, seja ele em qualquer âmbito, náo é gerado apenas através de experiências (contraponto a teorias baseadas apenas no comportamento, como o behaviorismo), mas, sobretudo, pela vivência das diferenças. Segundo Martins (1997, p. 120), "o aluno aprende imitando, concordando, fazendo oposiçấo, estabelecendo analogias, internalizando símbolos e significados, tudo isto num ambiente social e historicamente localizado".

Assim sendo, destacamos a importância de o processo de ensino/aprendizagem năo estar focado unicamente na figura do professor ou do aluno, mas no campo interativo criado pela colaboraçấo entre todos, mantendo uma prática baseada no constante diálogo entre os envolvidos, dando prioridade para um processo de aprendizagem contextualizado, amplo e que nâo se constitua de um ensino focado exclusivamente em questōes gramaticais.

À luz destas consideraçōes, na próxima seçâo apresentamos alguns aspectos da teoria de Bakhtin, para quem a linguagem é sinônimo de interaçăo social. 


\section{O DIALOGISMO DE BAKHTIN}

A linguagem é o principal tema da obra de Mikhail Bakhtin. O autor a compreende năo apenas como um sistema repleto de abstraçôes e, sim, como uma produçáo coletiva e, desta forma, tem necessidade de ser percebida a partir de sua natureza sócio-histórica. De acordo com Bakhtin (2010a, p. 40), a palavra penetra literalmente em todas as relaçôes entre os indivíduos, afirmando que "as palavras săo tecidas a partir de uma multidâo de fios ideológicos e servem de trama a todas as relaçôes sociais em todos os domínios".

Através da teoria bakhtiniana, podemos observar que o discurso de cada indivíduo se constrói, se (re)constrói e se desenvolve na e pela interaçăo social a partir de situaçóes e trocas significativas com os enunciados individuais alheios.

Dias e Silva (2005) salientam que para Bakhtin o olhar do outro funciona como se fosse um horizonte, que abriga novos valores, novas percepçōes e também novas visōes de mundo e é através do embate do nosso olhar com o dos outros que o novo conhecimento se multiplica. Partindo da ideia que o homem é um ser social, podemos entender que o homem năo deve renunciar a olhar o 'outro'.

Barros e Fiorin (2003, p. 3), ao refletirem sobre o conceito dialógico bakhtiniano da linguagem, o concebem como "o espaço interacional entre o eu e o tu ou entre o eu e o outro, no texto". Devido à importância da presença do 'outro', a noçăo do 'eu' nunca é somente individual e passa, obrigatoriamente, pela esfera do social. O dialogismo acontece no processo de troca e diálogo criado entre os sujeitos envolvidos, ou seja, é a prática da linguagem na relaçấo com o outro que dá impulso ao ser social. Em outras palavras, de acordo com a ótica de Bakhtin, os enunciados nâo existem separadamente, pois cada um leva em consideraçấo os que o antecederam e supôem os que o sucederâo.

Fazendo um paralelo entre os pressupostos teóricos de Bakhtin e Vygotsky, podemos perceber que, quando se opta por uma visáo sociointeracionista, a linguagem nâo deve ser concebida como um mero instrumento de informaçăo, de reproduçăo de ideias fragmentadas, mas, sim, como um caminho privilegiado por açóes calcadas nas interaçóes dos interlocutores. Nâo devemos apenas pensar em transmitir conhecimento e, sim, em (re)construir o conhecimento de maneira coletiva.

Desta maneira, entendemos que a língua é muito mais que elementos estruturais e gramaticais organizados em normas e regras fixas. Trata-se de uma entidade viva e dinâmica que náo é apenas usada pelos seres humanos, pois nós somos a língua e esta vai se adaptando e se metamorfoseando conforme as necessidades dos membros da sociedade que a compartilham.

Também compartilhamos a afirmaçăo de Bakhtin (2010b) de que nos comunicamos a partir de diferentes gêneros discursivos e que estes organizam a comunicaçăo de uma sociedade por terem estruturas relativamente estáveis. Isto é, embora os gêneros sejam reconhecidos por suas estruturas de composiçăo e especificidades, é possível reorganizá-los, na medida do possível, e dar-lhe uma nova roupagem, dependendo do objetivo comunicativo. Por exemplo, ao escrever uma carta, é possível fazê-lo a partir de um poema, de uma narraçăo, de um desenho ou até a partir de um enigma, mas sempre haverá um destinatário, remetente, saudaçăo e despedida. Isto quer dizer que, embora o conteúdo da carta possa adquirir diferentes formatos, os elementos estáveis 
do gênero ainda devem permanecer para que os membros da sociedade possam reconhecê-lo como o gênero carta.

Compreendemos que a língua está imersa em um contexto cultural estabelecido e que a questáo cultural está diretamente ligada com a maneira que nos pronunciamos, com a estrutura utilizada, a partir da escolha de campos lexicais, elementos fonéticos, etc. Também năo podemos deixar de ressaltar que a língua, quando vista como prática social, estará intimamente ligada a um objetivo comunicativo e que a gramática por si só, descontextualizada, náo é suficiente para dar sentido a um texto/enunciado.

Portanto, se o docente concebe a língua a partir de um olhar funcionalista, levando em consideraçăo as funçóes da linguagem, a aula de LE poderá ser um espaço rico em trocas culturais, no qual se ampliam os conhecimentos gramaticais necessários para toda e qualquer estrutura textual e discursiva. Explorando a língua sob este olhar, é possível ancorar os tópicos gramaticais em situaçōes comunicativas autênticas, desenvolvendo e aperfeiçoando a CC dos estudantes. E é sobre este tema que nos debruçamos na seçăo a seguir.

\section{CONCEITO DE COMPETÊNCIA LINGUÍSTICA E COMPETÊNCIA COMUNICATIVA}

Noam Chomsky é um teórico que se enquadra na vertente estruturalista da língua. Da mesma forma, seu conceito de competência linguística está intimamente atrelado a uma questăo estrutural. O autor define como competência linguística o conhecimento que o sujeito tem das estruturas gramaticais de sua língua e sua capacidade de usá-las. Isto é, reduz a linguagem ao conhecimento estrutural, deixando de fora outros fatores que atuam no discurso como, por exemplo, os elementos pragmáticos e semânticos de uma língua (OLIVEIRA, 2007).

Chomsky, em seu livro Aspectos da teoria da sintaxe, faz a conhecida distinçấo entre competência e desempenho. A primeira definiçáo designa o conhecimento do sistema linguístico que o falante tem da sua língua e que lhe permite produzir um conjunto de sentenças; também define o conjunto de regras que cada falante construiu mentalmente pela sua capacidade inata para a aquisiçấo da linguagem. Já o termo desempenho, Chomsky define como o uso que o falante faz desse conhecimento inato. Sobre aquisiçăo da LM, o autor afirma que

\footnotetext{
parece evidente que a aquisiçăo da linguagem se baseia na descoberta pela criança daquilo que, de um ponto de vista formal, constitui uma teoria profunda e abstrata - uma gramática gerativa de sua língua - da qual muitos dos conceitos e princípios se encontram apenas remotamente relacionados com a experiência através de cadeias longas e complexas de etapas inconscientes e de natureza quase dedutiva (CHOMSKY, 1975, p. 141).
}

Petter (2011) acrescenta que o desempenho resulta năo somente da competência linguística do falante. De um lado há os fatores năo linguísticos, como as convençōes sociais, crenças, atitudes emocionais do falante em relaçáo ao que profere, pressupostos sobre atitudes do interlocutor, entre outros elementos; de outro, está em jogo o funcionamento dos mecanismos de ordem psicológica e fisiológica envolvidos na produçấo dos enunciados. 
O conceito de CC encabeçado por Dell Hymes (1972), e mais recentemente por Michael Canale (OLIVEIRA, 2007), prevê uma série de questóes que năo foram levadas em consideraçăo por Chomsky. Hymes deixa claro que CC é um conjunto de conhecimentos, no qual, num primeiro plano, é necessário conhecer as regras gramaticais e estruturais da língua, mas também é necessário saber em quais situaçōes o sujeito pode utilizar as formas previstas na norma padrăo e em quais pode ser mais informal.

Hymes (1972, p. 60) explica seu ponto de vista afirmando que

o engajamento da língua/linguagem na vida social possui um aspecto positivo e produtivo. Há regras de uso sem as quais as regras gramaticais seriam inúteis. Assim como regras de sintaxe podem controlar os aspectos da fonologia, e assim como as regras semânticas podem talvez controlar aspectos da sintaxe, as regras dos atos de fala podem emergir como um fator de controle para uma forma linguística como um todo (traduçăo nossa). ${ }^{3}$

Nesse sentido, nosso discurso năo seria facilmente compreendido se năo fosse dotado de pelo menos três características básicas e inerentes à linguagem: adequaçăo, coesăo e coerência. Por exemplo, ao dizermos a seguinte frase: "Gostaria de ficar em casa todos os dias para náo precisar trabalhar", a reconhecemos como correta, gramaticalmente falando. No entanto, se proferida em uma entrevista de emprego, torna-se inadequada, já que a funçâo da entrevista é pleitear uma vaga de trabalho. Após ouvir esta frase, possivelmente o entrevistador năo pensará duas vezes antes de descartar este candidato ao posto disponível.

Daniel Cassany (2010), ao discursar sobre o código escrito, esclarece que é necessário ter o conhecimento das regras de adequaçăo, coesăo e coerência, além das regras fonéticas e morfossintáticas da língua. A adequaçăo serve como orientaçăo para o interlocutor no momento da sua interaçâo comunicativa. Dependendo da situaçấo, o enunciador poderá optar pelo uso do registro formal ou informal, por informaçóes mais gerais ou específicas, ou ainda fazer uso de dialetos ou da norma padráo. No que tange à coesăo e à coerência, estes sâo elementos essenciais para qualificar o texto, seja este oral ou escrito. $O$ primeiro refere-se ao enlace entre as ideias, à uniăo de uma frase com a outra, e pode ser caracterizada como a linha que alinhava a borda de um tecido, deixando-o unido e terminado. A coerência faz alusáo às questóes de composiçấo do texto, sua estrutura e conjunto de regras gramaticais que garantem o significado daquilo que está sendo dito. A frase sobre a entrevista de trabalho ilustrada acima pode ser usada como exemplo de falta de coerência e adequaçáo à situaçáo comunicativa. Portanto, o contexto situacional é determinante e "estabelece regras para o uso das frases de acordo com o contexto em que o falante-ouvinte se encontra" (OLIVEIRA, 2007, p. 66).

Dito de outra maneira, devemos levar em consideraçâo que, quando falamos ou escrevemos, nâo queremos unicamente expressar ideias, mas também produzir textos de acordo com uma série de normas sociais e situaçóes comunicativas que requerem o uso contextualizado da linguagem, nas quais devemos nos fazer uma série de

3 The engagement of language in social life has a positive, productive aspect. There are rules of use without which the rules of grammar would be useless. Just as rules of syntax can control aspects of phonology, and just as semantic rules perhaps control aspects of syntax, so rules of speech acts enter as a controlling factor for linguistic form as a whole. 
questionamentos, como, por exemplo: quem é o emissor do texto/enunciado4?; a quem vai dirigido meu discurso?; qual é o tema abordado?; qual será o veículo de circulaçâo deste texto/enunciado?; qual é a intençâo/propósito comunicativo (descrever, narrar, argumentar, convencer, etc.)?, entre outras questôes. Todos esses fatores influenciam diretamente na hora de se produzir um discurso, seja ele oral ou escrito, e năo podem ser negligenciados, uma vez que a língua, quando concebida de forma estritamente gramatical, muito provavelmente náo dará conta de todos os fatores levantados acima.

Seara e Nunes (2010) ressaltam que, para que o aluno tenha uma aprendizagem significativa e seja capaz de desenvolver as quatro habilidades - compreensâo e produçâo oral e escrita - é adequado pensarmos nas competências que devem ser dominadas a fim de que se tenha uma CC em LE. Săo elas:

- saber diferenciar as variantes linguísticas;

- saber fazer uso adequado da linguagem (registro) de acordo com a situaçâo na qual se dá o ato comunicativo;

- escolher o vocabulário que melhor defina a ideia que se pretende comunicar;

- compreender que determinadas expressōes sâo influenciadas por aspectos sociais e/ou culturais nos quais estăo inseridas;

- perceber que o discurso reflete a forma de ser, pensar e agir no mundo daquele que o proferiu;

- utilizar os mecanismos de coerência e coesâo na produçâo de textos (sejam orais ou escritos) em LE, de forma que possam ser entendidos;

- utilizar estratégias verbais e nâo verbais para compensar possíveis lacunas na comunicaçăo.

Como podemos perceber, os itens apresentados e discutidos acima perpassam o nível formal da língua e văo mais além, demonstrando que, para almejar uma CC em LE, o aluno necessita passar por uma série de situaçóes em sala de aula que possibilitem o uso da língua de forma contextualizada. Para isso, o conceito de língua do docente será determinante.

\section{A FERRAMENTA TRADUTÓRIA SOB A ÓTICA FUNCIONALISTA EM AULA DE LE}

Através de nossa experiência como docentes de LE, frequentemente observamos que se tem atribuído à ferramenta tradutória uma visăo negativa dentro de sala de aula por diferentes motivos, tanto por parte de alunos como de docentes de línguas. Uma destas razóes é a afirmaçăo de que a traduçâo afasta o aluno do exercício de pensar em LE, pois, a partir do momento em que faz uso desta ferramenta, está recorrendo à língua materna (LM), o que supostamente seria prejudicial ao aprendizado do aluno.

Outro motivo que pode justificar o rechaço da ferramenta tradutória pelos professores em sala de aula é a herança que o Método Gramática e Traduçăo (MGT) ainda deixa nas metodologias de ensino de LE. Quando utilizada no MGT, a traduçăo era

4 Neste caso entendemos texto e enunciado como termos intercambiáveis, a exemplo de Cassany (2008). 
trabalhada de forma mecânica, em que nâo se exigia a reflexâo por parte dos alunos sobre elementos importantes como público receptor, elementos culturais e históricos envolvidos, funçâo textual, gênero discursivo, propósito comunicativo, entre outros.

No contexto do MGT, o texto era visto como algo sagrado, no qual năo se poderia fazer nenhuma mudança com relaçăo à sua estrutura linguística, à sua forma. Esta visăo ainda faz parte do imaginário de muitos docentes que, por consequência, transmitem o mesmo entendimento aos seus estudantes, pela forma como orientam as atividades em sala de aula, nos raros momentos em que a traduçáo é explorada.

No entanto, é importante que os docentes de LE se perguntem e reflitam sobre como aprendem os seus alunos. É recorrente observar que estes se sentem seguros ao usar a traduçăo como uma maneira de confirmaçăo do aprendizado, bem como, e muito importante, para fazer um contraste do conhecimento prévio (sua LM) com o novo conhecimento (conteúdos, expressōes, elementos fonéticos, sintáticos e retóricos do novo idioma).

O cotejamento entre os dois códigos linguísticos e culturais presentes em sala de aula é um processo natural e nâo deve ser orientado e direcionado como algo negativo pelo docente. Ainda que existam muitos professores que o façam, talvez motivados pela abordagem comunicativa, náo se obtêm resultados positivos, pois o estudante utilizará a traduçâo interiorizada, a qual, segundo Hurtado Albir (2001), refere-se a qualquer forma espontânea de comparaçăo entre as línguas envolvidas.

Ora, como é possível tentar tolher qualquer tipo de traduçâo feita pelo estudante, enquanto este o faz para confirmar um novo conhecimento? Certo está que traduzir de forma desenfreada é praticamente ministrar as aulas na LM do aluno e năo é isto que aqui defendemos. Propomos um trabalho mais completo com a traduçăo a fim de ampliar a CC do estudante, a partir do momento em que se valorizam os elementos culturais de um exercício tradutório e pensa-se na linguagem como prática social.

Ao partimos do pressuposto de que a traduçăo é algo inevitável no processo de ensino e aprendizagem de LE, nos perguntamos por que năo utilizar esta ferramenta de modo a criar um ambiente de reflexâo e discussăo? A fim de facilitar tal espaço para discussóes, propomos exercícios tradutórios que fujam dos tradicionais "leia e traduza", que muitas vezes encontramos nos livros didáticos que atualmente circulam no mercado brasileiro. Desta forma, o aluno se aproximará de outras formas de identidade cultural, de expressóes idiomáticas da língua estudada, assim como de questóes estruturais dos gêneros discursivos, que podem mudar de acordo com a nacionalidade e o contexto de circulaçăo.

Com vistas a criar um espaço para explorar a traduçăo de maneira mais adequada, recorremos à teoria de traduçâo funcionalista de Nord (2010), para a qual săo importantes, no processo tradutório, elementos como destinatário, intençâo do texto base, culturas base e meta, normas e convençôes das línguas envolvidas, etc. Ou seja, a traduçâo é compreendida como uma ponte entre culturas, na medida em que o tradutor/ aluno năo pode deixar de considerar os elementos do texto base para criar estratégias tradutórias ao pensar em seu destinatário.

Dentro do âmbito da traduçăo funcionalista, sob o olhar nordiano, entende-se que todo texto tem a funçáo de comunicar e o autor do texto base tem sempre uma intençấo ao produzi-lo. Isto deve ser levado em consideraçáo no momento da traduçấo, em 
consonância com o receptor do texto traduzido, figura que deverá estar em constante presença na tomada de decisóes tradutórias que se farăo ao longo da traduçăo.

Assim sendo, a traduçấo desenhada desta forma possibilita verificar, analisar e contrastar as diferenças, tanto linguísticas quanto culturais, de forma mais profunda e funcional. Quando se tem o desafio de traduzir, é necessário envolver mais elementos como público destinatário e seu contexto sociocultural, motivo, funçăo do texto traduzido, intençâo do autor do texto original, etc. É neste ponto que entra o professor, cujo papel é determinante para uma atividade tradutória bem-sucedida, de forma que este assume o papel de mediador no processo de ensino e aprendizagem do aluno, tentando suprir as possíveis lacunas linguísticas e culturais que o aluno possa apresentar, facilitando e orientando-o para um melhor processo tradutório.

\section{A TRADUÇÃO FUNCIONALISTA EM PRÁTICA}

Em primeiro lugar gostaríamos de destacar que a atividade proposta está baseada nos pressupostos de Schneuwly, Noverraz e Dolz (2004, p. 82), que afirmam que uma SD "é um conjunto de atividades escolares organizadas, de maneira sistemática, em torno de um gênero textual oral ou escrito". A estrutura que compôs a SD proposta está igualmente inspirada nas orientaçōes dos mesmos autores, a partir do esquema ilustrado abaixo:

Figura 1: esquema da sequência didática

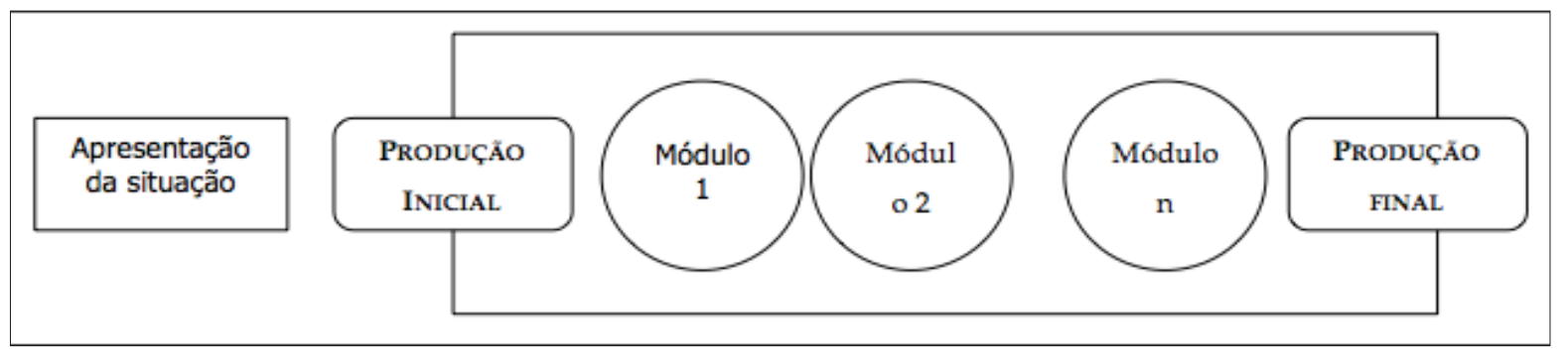

fonte: SCHNEUWLY, NOVERRAZ E DOLZ, 2004, p. 82

Como já mencionado, a SD foi aplicada junto às quatro alunas matriculadas na disciplina de "Estudos Avançados em Língua Espanhola I: prática de textos", no mês de abril de 2015. A atividade proposta foi dividida em sete etapas, de forma que todos os movimentos foram previstos no cronograma de atividades e contemplados no plano de ensino da disciplina, totalizando $16 / \mathrm{H}$ de atividades.

Para melhor ilustrar todas as etapas que compóem a SD proposta, descrevemos a seguir cada uma delas de forma individual e, paralelamente, tecemos comentários advindos da observaçáo de cada etapa. Em seguida, apresentamos a discussáo dos dados obtidos durante o desenvolvimento da SD.

\section{$1^{a}$ ETAPA - CONTEXTUALIZAÇÁO DAS TIRINHAS DA MAFALDA}

A primeira etapa da SD teve como objetivo principal conscientizar as alunas do contexto extralinguístico das tirinhas da Mafalda. Para isso, a primeira açăo realizada 
foi a de orientar as participantes a fazerem uma pesquisa extraclasse sobre o criador da Mafalda (Quino), na qual buscaram informaçōes sobre o contexto sócio-históricocultural em que as tirinhas foram criadas e sobre o perfil de cada personagem contido nas historinhas. Esta etapa foi feita em casa pelas estudantes e cada uma trouxe para a sala de aula o resultado de suas pesquisas.

Durante a socializaçăo das informaçóes coletadas, as estudantes puderam observar que as tirinhas da Mafalda foram criadas nas décadas de 60 e 70, retratando realidades importantes do contexto cultural argentino daquela época, bem como questóes políticas e sociais em contexto mundial; igualmente observaram que os personagens criados por Quino possuem características marcantes e cada qual cumpre uma funçáo dentro das histórias. O compartilhamento dessas e outras questóes levantadas pelas alunas teve como objetivo principal afinar o olhar sobre o contexto a ser trabalhado e prepará-las para a segunda etapa da SD, detalhada a seguir.

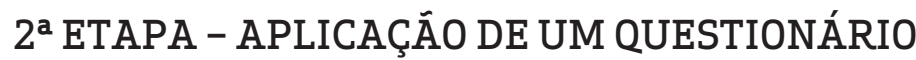

A segunda etapa teve como objetivo principal conhecer as opiniōes das estudantes sobre os seus conceitos de traduçăo. Para isso, aplicamos um questionário com perguntas abertas com o intuito de diagnosticar concepçōes pré-concebidas de traduçáo por parte das alunas. O questionário continha três perguntas, ilustradas abaixo:

a) - ¿Para ti, qué es traducción? Explícalo con tus palabras; b) - ¿Crees que para ser traductor es necesario ser bilingüe ${ }^{5}$ o haber vivido en el país donde se habla la lengua extranjera con la cual se trabaja? Justifica la respuesta; c) - ¿Qué elementos consideras importantes al momento de traducir? Justifica tu respuesta.

Ao analisarmos as respostas dadas pelas alunas, percebemos que das quatro estudantes, duas mencionaram o termo cultura em resposta à primeira pergunta, como vemos nos trechos ${ }^{6}$ ilustrados abaixo. ${ }^{7}$

Aluna 1: Traducción no se resume solo como un processo de traducir palavras de una lengua para otra, además de eso, traducción es la lectura de acontecimentos, culturas y modos de vivir de una sociedade o contexto.

\section{Aluna 2: [...] para esto, muchos otros factores tienen que ser considerados como el momiento histórico de la escritura, el autor, el país, cultura en que está inserido.}

De acordo com os excertos acima, parece que para estas duas alunas - ainda que năo tenham passado por disciplinas obrigatórias sobre traduçăo ao longo do curso -, existem alguns elementos que fazem parte do processo tradutório, os quais devem

5 Aqui entendemos o termo "bilíngue" como o uso de duas línguas por um falante (ou grupo de pessoas), de maneira simultânea, com proficiência ou com a predominância de uma delas.

6 Com o objetivo de diminuir o 'volume' de texto apresentado pelas alunas participantes da pesquisa, optamos por năo apresentar as respostas na íntegra, apenas os excertos que julgamos serem mais significativos com relaçâo às perguntas contidas nos questionários. Vale lembrar que a análise foi feita com base nas respostas completas, sendo os excertos apontados neste trabalho uma síntese da opiniâo de cada estudante.

7 As respostas foram reproduzidas sem alteraçōes e/ou correçōes gramaticais da língua espanhola. 
ser levados em consideraçáo. Ao que tudo indica, duas das estudantes entendem que o fator cultural é relevante para o produto tradutório, bem como pensar no respectivo destinatário.

As outras duas estudantes descreveram a traduçáo como um processo de decodificaçáo entre uma língua e outra, como é possível observar nos trechos ilustrados abaixo:

Aluna 3: Traducción es traducir algo, sea de una lengua para otra o hechos ocurridos.

Aluna 4: [La traducción] Puede ocurrir entre lenguas extranjeras como en una misma lengua. Traducir es dar sentido a una frase, se for una frase extranjera es producir sentidos en la lengua materna.

Através das respostas dadas pelas alunas, podemos inferir que ambas parecem náo ter muito claro que o conceito de traduçăo "é bem mais amplo do que a simples passagem de uma língua para outra", como bem afirmam Batalha e Junior (2007, p. 10). As alunas percebem a traduçăo como mera transposiçăo linguística, sem levarem em consideraçăo outros fatores como: os elementos extralinguísticos, as culturas envolvidas, o contexto social, o público-alvo etc. Conforme as respostas ilustradas acima, podemos observar que a última aluna parece reduzir a traduçấo a uma açáo de correspondência "frase por frase", dando valor aos elementos constitutivos de uma frase de maneira isolada.

Com relaçâo à segunda pergunta (b) - ¿Crees que para ser traductor es necesario ser bilingüe o haber vivido en el país donde se habla la lengua extranjera con la cual se trabaja? Justifica la respuesta), duas alunas responderam de forma negativa:

Aluna 1: Creo que no. Sabemos que el sentido de bilinguismo es amplo, pero es indispensable para un traductor conocer los elementos culturales del país escogido, de la lengua extranjera que se va a trabajar.

Aluna 3: Creo que no, pero para uno traducir alguna cosa escrita es necesario que sepa muy bien la lengua en que vá traducir o para la cual esta traduciendo.

Para estas alunas, os conhecimentos que um tradutor deve ter năo chegam a um nível de bilinguismo, como também náo é importante o fato de morar no país estrangeiro da língua trabalhada por ele.

Entretanto, as outras duas alunas nos revelam respostas diferentes:

Aluna 2: Para la traducción de una lengua para otra acredito que ser bilíngue en alguno "grau" o haber vivido en el país sea importante. (....)

Aluna 4: Un traductor puede ser sólo bilíngue y ser un bueno traductor de lengua extranjera, pues, el importante es conocer todos los sentidos que existen para las palabras, las expresiones idiomáticas, la cultura de la lengua y saber pasar para la otra lengua. 
Como podemos observar, as duas alunas apontam o bilinguismo como um fator a ser considerado para o exercício da traduçăo. Pagano (2000) afirma que esta é uma visâo muito recorrente entre os aprendizes de traduçăo, e que essas percepçōes que se tem sobre o que é traduçăo, o papel do tradutor, entre outras questôes, afetam diretamente o papel a ser desenvolvido pelo aluno/tradutor. Para a autora, ser bilíngue é um fator que facilita o trabalho de traduçăo, porém, este náo assume caráter de exclusividade, pois é apenas um dos elementos que fazem parte do que ela denomina como sendo "competência tradutória". ${ }^{8}$ Ademais, a autora ressalta que este pensamento está inserido entre as cinco crenças limitantes mais comuns dentro do processo de ensino e aprendizagem da traduçáo e influencia diretamente na forma como a sociedade avalia esta profissâo e seus respectivos profissionais.

Com relaçăo à última pergunta do questionário, sobre quais săo os elementos importantes para uma traduçâo, as alunas valorizaram, em maior medida que na primeira pergunta, os elementos culturais e outros elementos que fazem parte do processo de tradução, como podemos observar nos excertos abaixo:

Aluna 1: Conocimientos básicos de la lengua, gramaticales, culturales, históricos.

Aluna 2: Estar concentrado, tener un conocimiento básico del assunto a ser traducido, tener un diccionário, tener algunos conocimientos culturales para compreender frases y expresiones idiomáticas.

Aluna 3: Conocimientos de las lenguas, conocimientos del contexto en que se ha producido el documento o la noticia, la própria historicidad del traductor, la convencionalidad.

Aluna 4: Es importante conocer la cultura del Pueblo, los costumbres, los valores sociales, las expresiones idiomáticas o ditados.

A partir dessas respostas, podemos observar que as alunas, de maneira geral, se preocupam em observar alguns elementos importantes a serem considerados durante o ato tradutório, a exemplo das questōes culturais, históricas, o contexto no qual está inserido o texto de partida, indo além das noçôes linguísticas que săo de suma importância, porém nâo a única habilidade a ser exigida de um tradutor.

\section{$3^{\mathrm{a}}$ ETAPA - APRESENTAÇĀO DA TEORIA FUNCIONALISTA DE TRADUÇÁO}

Após a aplicaçâo do questionário na etapa anterior, a terceira etapa teve como objetivo principal apresentar às alunas os pontos mais importantes da teoria funcionalista de tradução de Nord. Portanto, este momento foi importante para a SD, pois as estudantes, até aquele momento, năo haviam cursado nenhuma disciplina que versasse sobre traduçăo na graduaçâo, como já mencionado, e, tampouco, haviam elaborado

8 O conceito de competência tradutória abordado neste trabalho está ancorado nos estudos do grupo PACTE, da Universidade Autônoma de Barcelona, coordenado pela professora doutora Amparo Hurtado Albir. Para o PACTE a competência tradutória (CT) " (i) é o sistema subjacente de conhecimentos, habilidades e aptidôes necessários para traduzir; (ii) é qualitativamente diferente da competência bilíngue; (iii) está formada por um conjunto de subcompetências, nas que existem relaçóes, hierarquias e variaçôes" (2001, p. 3). 
traduçōes em ambiente extraescolar. Como entendemos que toda prática pedagógica está permeada por elementos teóricos, proporcionamos às alunas uma contextualizaçấo da teoria funcionalista de traduçấo de Nord (2010) para que tivessem mais condiçóes de realizar as traduçóes e mais segurança no momento de tomar decisóes e criar estratégias tradutórias.

Este momento foi realizado através da leitura e debate de textos de autoria da teórica alemá, de forma que as alunas pudessem esclarecer suas dúvidas, compartilhar o novo conhecimento com as demais colegas e perceber os preceitos básicos desta teoria. As leituras foram feitas de forma individual e extraclasse, e as acadêmicas destacaram os pontos que consideraram mais relevantes da teoria funcionalista de traduçăo.

Um desses pontos foi o esclarecimento de dois conceitos chaves para a área dos Estudos da Traduçấo: o da fidelidade e o da equivalência. Ambos os conceitos săo muito discutidos por diversos teóricos e sâo considerados polêmicos por gerarem diferentes opiniōes baseadas em diferentes vertentes teóricas. Nord (2010) propōe que a fidelidade năo seja medida pela literalidade da traduçăo com relaçăo ao texto fonte, e sugere que o tradutor deva ser fiel à intençăo comunicativa do autor. A equivalência também segue a mesma lógica, ou seja, os textos săo considerados equivalentes a partir de uma análise que perpassa o âmbito puramente linguístico. Se os dois textos permitem uma interaçáo comunicativa com seus respectivos destinatários e atingem as funçôes anteriormente planejadas, podem ser considerados equivalentes segundo a teoria funcionalista de traduçăo.

A discussâo foi finalizada com um fechamento geral realizado pela professora da disciplina, a fim de sinalizar os pontos chaves da teoria em questâo e sanar possíveis dúvidas ou más interpretaçōes que surgiram no decorrer no debate coletivo.

Com base nos pontos da teoria nordiana, as estudantes partiram para a quarta etapa da SD, apresentada a seguir.

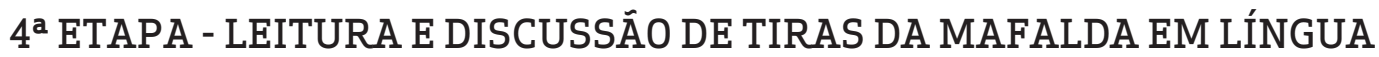 ESPANHOLA}

A quarta etapa teve como objetivo principal a discussăo sobre os possíveis problemas de traduçăo presentes nas tirinhas pré-selecionadas (ilustradas abaixo). Estas foram selecionadas por apresentarem alguns elementos linguísticos que oferecem certo grau de desafio tradutório às alunas envolvidas. Săo textos que contêm estruturas e expressôes bem específicas do país de origem, algo que requer mais cuidado do aluno/ tradutor, que terá que refletir sobre questóes linguísticas e culturais no momento de traduzir. Esta etapa também teve como foco provocar nas alunas uma conscientizaçăo de que todo texto năo se apresenta acabado em si mesmo, ou seja, está permeado por elementos culturais, sociais e históricos que fazem parte da interpretaçâo e compreensăo do seu conteúdo. Posteriormente à análise das tirinhas selecionadas, as alunas perceberam que todo texto a ser traduzido deve ser analisado desde diferentes ângulos, e năo somente sob a ótica meramente linguística.

Durante o processo de observaçăo e análise das tirinhas a serem traduzidas pelas alunas, elas perceberam e comentaram que a tarefa tradutória năo seria fácil devido aos desafios tradutórios que teriam pela frente. As expressōes usadas nas tiras 
causaram certo desconforto nas alunas ao tentar encontrar um equivalente em sua LM. As tirinhas selecionadas foram as seguintes:

a)
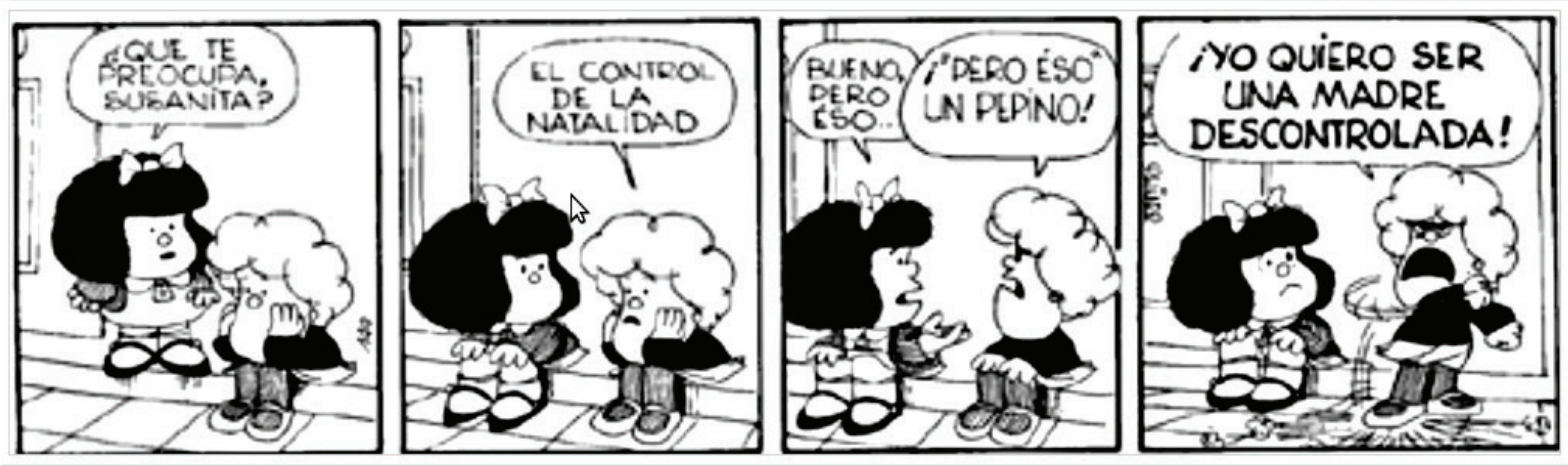

Fonte: Quino (2007, p. 83)

b)

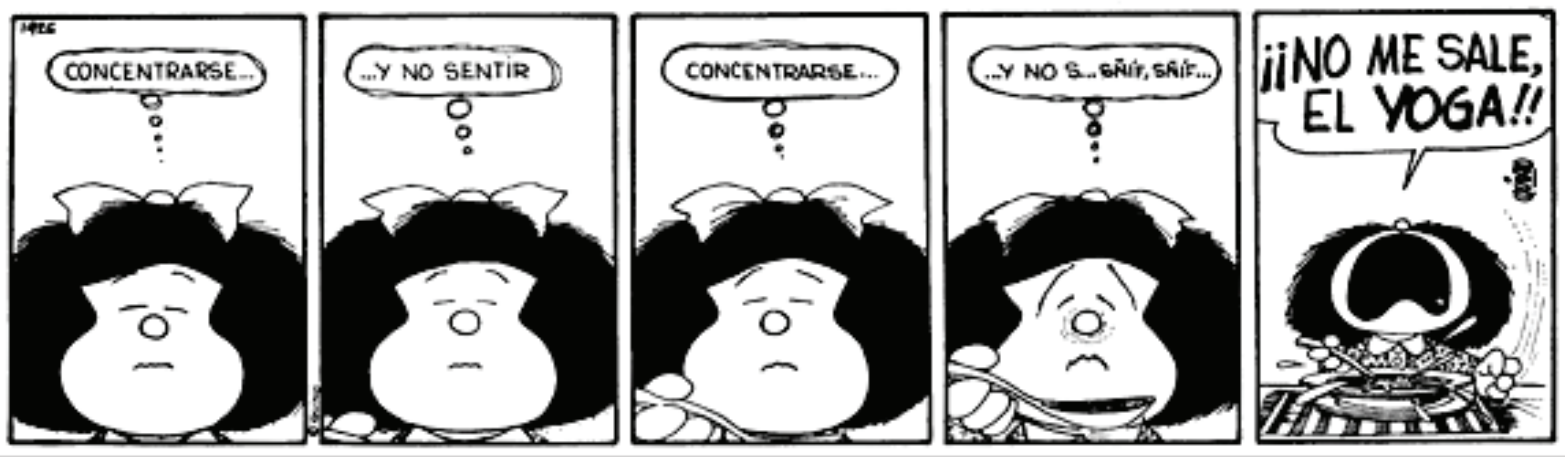

Fonte: Quino (2010, p. 405)

c)
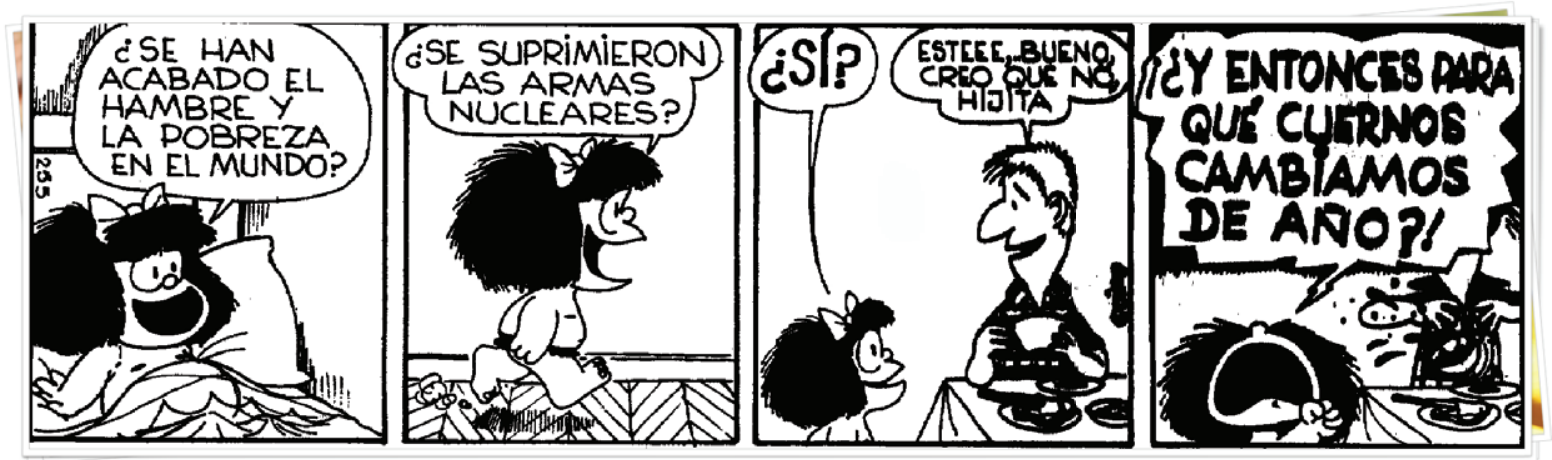

Fonte: Quino (2007, p. 255) 
d)
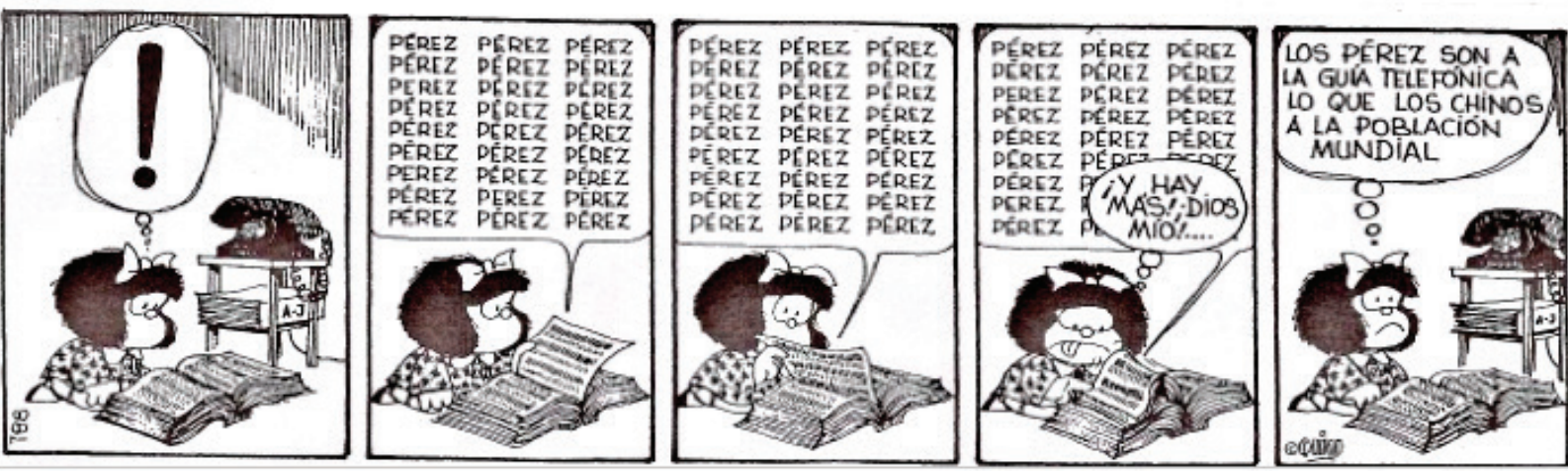

Fonte: Quino (2007, p. 244)

\section{$5^{\mathrm{a}}$ ETAPA - TRADUÇĀO DAS TIRAS}

A quinta etapa teve como objetivo proporcionar o momento da traduçáo das tirinhas discutidas anteriormente. Neste momento, as quatro estudantes, divididas em duas duplas, tiveram que traduzir as tirinhas que estavam em língua espanhola ao público brasileiro e, mais especificamente, traduzi-las, ainda que de maneira fictícia, para um jornal de circulaçấo local, editado e publicado na cidade de Chapecó/SC.

A atividade tradutória foi elaborada em sala de aula e a professora esteve presente durante toda a atividade tradutória, com o objetivo de mediar e orientar o processo, bem como tirar possíveis dúvidas das alunas. Durante a elaboraçâo da atividade estava permitido o uso de dicionários físicos e online.

Ao iniciarem o trabalho de traduçăo propriamente dito, e alicerçadas nas reflexôes e conhecimentos adquiridos nas etapas anteriores, as alunas puderem perceber que quando se tem consciência para quem se traduz um texto, o aluno/tradutor tem melhores condiçôes de fazer suas escolhas e elaborar um trabalho mais adequado de acordo com o contexto no qual o leitor alvo está inserido e, portanto, poderá realizar uma traduçăo funcional, de acordo com os pressupostos da teoria funcionalista de traduçâo. Nord (2010, p. 64) afirma que o "destinatário é um fator pragmático importante no processo tradutório", e, muitas vezes, acaba sendo a figura central da atividade de traduçăo, dependendo do gênero discursivo envolvido.

Durante o trabalho de traduçâo das tirinhas, as alunas se mostraram interessadas e participativas. As duplas trocaram ideias, fizeram negociaçōes com relaçâo aos seus resultados e discutiram suas escolhas tradutórias, proporcionando um ambiente de colaboraçăo entre os pares.

\section{6 ${ }^{\mathrm{a}}$ ETAPA- SOCIALIZAÇĂO DAS TRADUÇÓES}

A sexta etapa teve como objetivo possibilitar um momento para a socializaçáo das traduçóes das duas duplas e para a discussăo das decisôes tradutório-linguísticas realizadas pelas alunas. Com o auxílio de um projetor, as alunas compartilharam suas traduçōes, juntamente com as tirinhas originais, de forma que todas pudessem observar e analisar as traduçóes realizadas pelas companheiras. 
A seguir apresentamos as traduçóes realizadas pelas alunas:

$1^{\text {a }}$ tirinha:
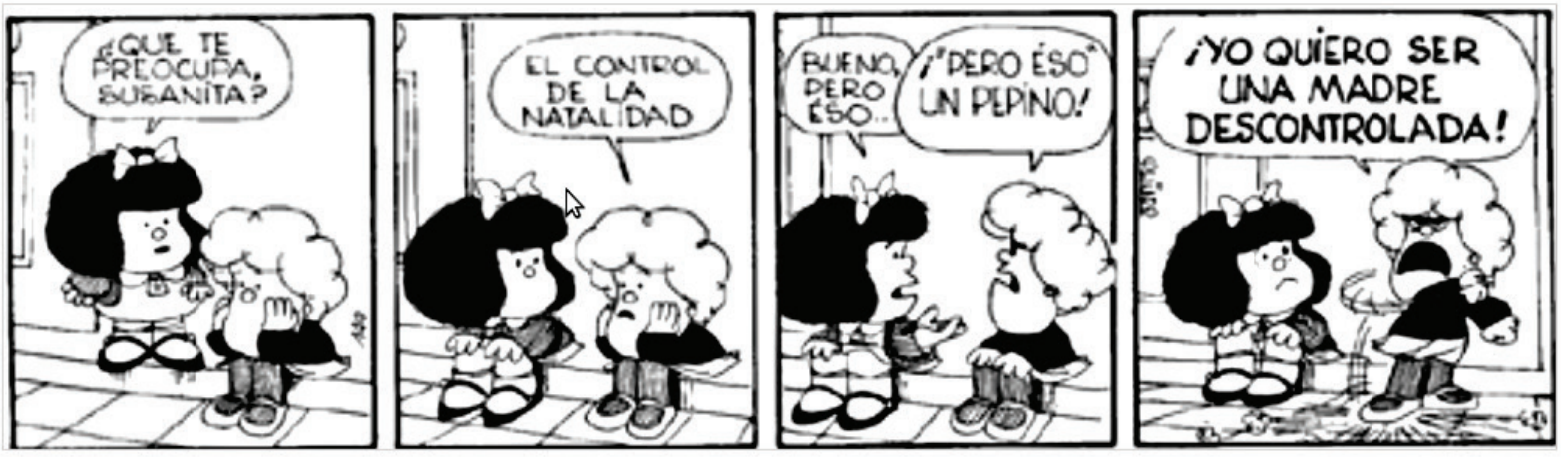

Nesta primeira tirinha, aparecem Mafalda e sua amiga Susanita, na qual a segunda mostra preocupaçăo quanto ao controle da natalidade, uma vez que ela tem desejo de ter muitos filhos. Mafalda diz năo entender a preocupaçăo da amiga e Susanita responde de maneira irônica: ¡Pero eso un pepino!, expressando um sentimento de desprezo pelo controle de natalidade, e conclui dizendo que quer ser uma máe descontrolada. Uma traduçăo ao pé da letra, ou seja, literal, muito provavelmente causaria certo estranhamento para o público brasileiro, uma vez que nâo usamos esta expressâo (com as mesmas palavras), como no espanhol. Para tanto, as alunas tiveram a tarefa de pensar no público-alvo ao qual estava direcionada a traduçăo. Vejamos as soluçōes encontradas pelas duas duplas:

\section{Espanhol \\ ¡Pero eso un pepino!}

Português

(dupla 1) Mas isso nada

(dupla 2) Isso uma ova

Dessa forma, acreditamos que as alunas puderam perceber que a expressâo de uma determinada cultura nem sempre será entendida da mesma maneira quando traduzida para uma cultura diferente e que, portanto, é preciso adequá-la ao entorno cultural do público meta. As duas expressôes mencionadas acima săo informais e também conhecidas pelos brasileiros de maneira geral.

\section{$2^{\text {a }}$ tirinha:}
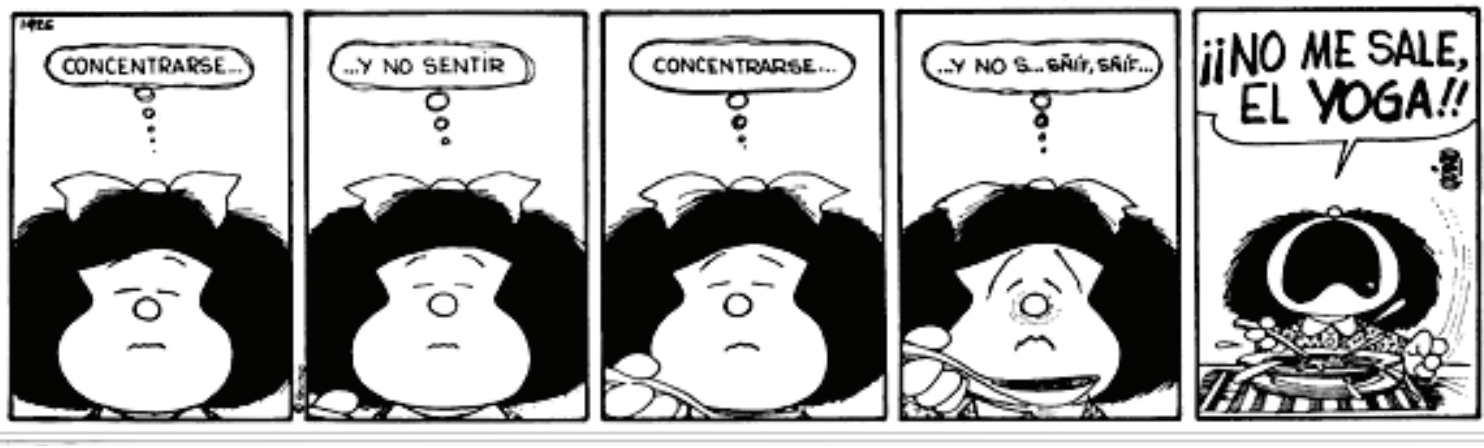
Na tirinha acima faz-se necessário entender uma caraterística muito marcante na personagem Mafalda - ela odeia tomar sopa. Podemos observar que ela se esforça para tomá-la, mas é algo que lhe custa muito. Inclusive, ela busca ânimo nos preceitos do yoga, como a concentraçăo, para cumprir a sua missăo. No último quadrinho encontramos uma expressâo muito típica da língua espanhola - "no me sale", que podemos usar em vários contextos distintos, como "el portugués no me sale", que quer dizer que, para essa pessoa, a língua portuguesa é muito complexa e por isso năo consegue aprendê-la. Se fosse traduzida tal qual está no espanhol para o português, năo faria sentido algum. Vejamos as duas opçóes traduzidas pelas alunas:

Espanhol

¡Pero eso un pepino!
Português

(dupla 1) Mas isso nada

(dupla 2) Isso uma ova

A primeira dupla optou por continuar usando a palavra "yoga" em sua traduçăo. Neste caso a traduçấo faz mençâo ao fato de Mafalda se esforçar e buscar ânimo na suposta força que a prática de yoga proporciona aos seus praticantes, bem como no quadrinho-base. Na segunda traduçấo, a dupla fez alusăo ao fato real de que Mafalda nâo suporta comer sopa e opta por deixar explícita esta característica na traduçấo, eliminando a palavra "yoga", mas sem dar o real sentido do texto base.

$3^{\mathrm{a}}$ tirinha:
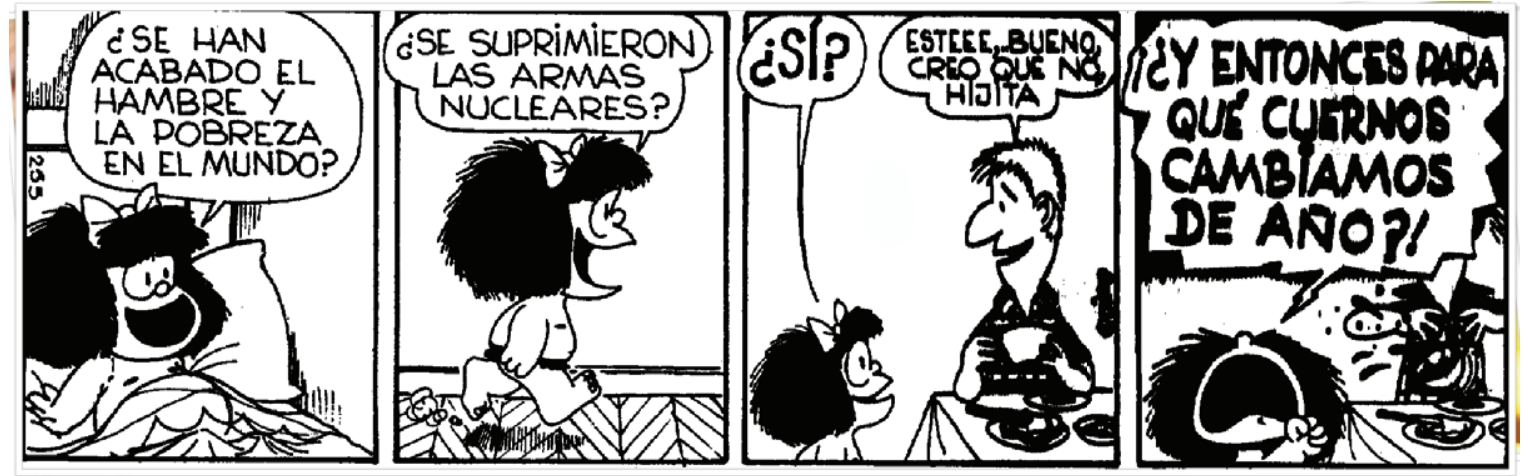

Na terceira tirinha apresentada, Mafalda expressa seu desejo, através de perguntas ao seu pai, de que se acabem os problemas mundiais, como, por exemplo, a fome e a existência das armas nucleares. ${ }^{9}$ Podemos perceber que o pai de Mafalda titubeia para responder, reaçăo normal que ele esboça toda vez que Mafalda lhe faz perguntas desse nível, uma vez que a filha sempre o surpreende com questionamentos muito elaborados para uma menina de sua idade. Sendo ela muito curiosa e contestadora, ele muitas vezes năo tem resposta para lhe dar. Ao final, Mafalda usa a expressâo "Y entonces para qué cuernos cambiamos de año", para demonstrar que está muito decepcionada

$9 \quad$ Esse tipo de pergunta é recorrente na personagem e é a que mais faz críticas à sociedade e tem o papel de trazer a racionalidade para as discussôes entre os personagens. 
e indignada com os problemas mundiais e que náo faz menor diferença ter passado mais um ano se estes problemas ainda continuam. Vejamos abaixo algumas escolhas tradutórias realizadas pelas alunas, focando-nos nos últimos dois quadros:

Espanhol

Esteee...Bueno, creo que no, hijita

¿¿Y entonces para qué cuernos cambiamos de año?;

\section{Português}

(dupla 1) Baah, acredito que năo, filha (dupla 2) Éééé....bom, acho que náo, pequena

(dupla 1) Mas entăo, por que diabos mudamos de ano?

(dupla 2) E entâo por que diabos mudamos de ano?

Nas traduçôes acima apareceram duas formas diferentes de traduzir o titubeio do pai de Mafalda: "Esteee...Bueno, creo que no, hijita". A dupla 1 justificou sua traduçâo ao pensar no público chapecoense, que tem muitas tradiçóes gaúchas, tanto na fala, quanto em outras esferas sociais como comidas e bebidas típicas. Portanto, entendem que sua traduçâo foi funcionalista por levar o destinatário em consideraçăo, inserindo o vocábulo "bah", muito característico desta regiăo do país. Na segunda parte - "i¿Y entonces para qué cuernos cambiamos de ańo?!", percebemos que ambas as duplas optaram quase pela mesma expressâo, substituindo cuernos do espanhol por "diabos", que é usada no Brasil e reconhecida semanticamente em muitas regiōes, incluindo a regiăo Sul. Segundo manifestaçōes das próprias participantes, podemos intuir que as alunas perceberam que a palavra cuernos nâo teria o mesmo efeito no seu público-alvo, uma vez que, se a expressăo fosse traduzida literalmente (cornos), teria causado estranhamento em nossa cultura.

\section{$4^{\mathrm{a}}$ tirinha:}
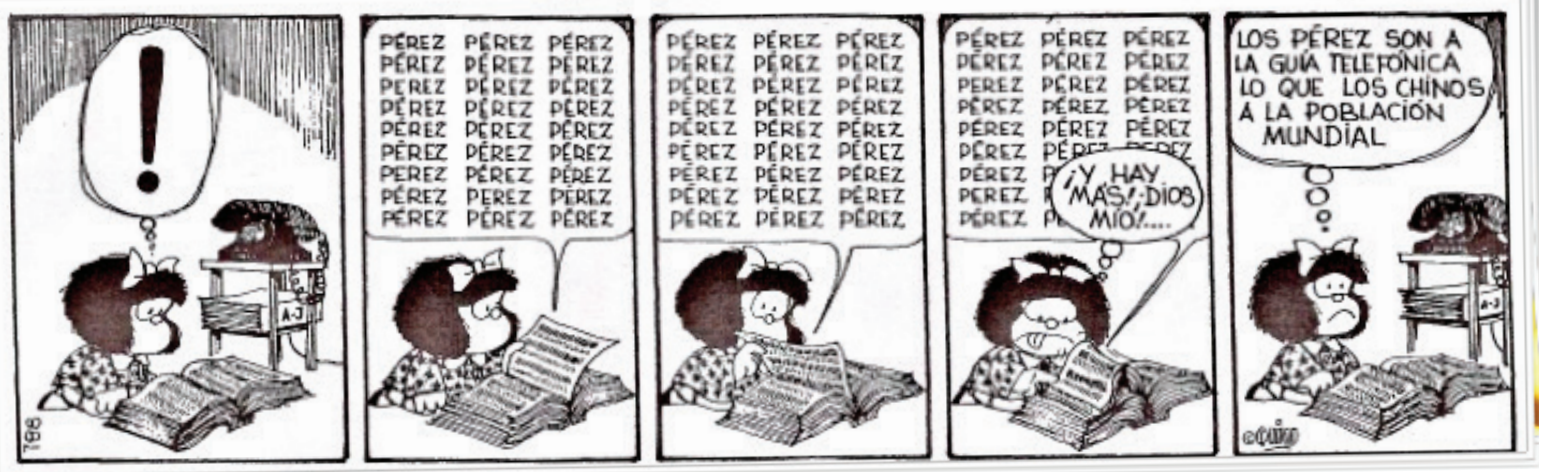

Na quarta tirinha apresentada às alunas, Mafalda folheia a lista telefônica e observa que existe uma quantidade expressiva de pessoas com o sobrenome "Pérez". Sua surpreendente constataçăo leva a astuta personagem de Quino a fazer uma analogia com relaçáo a quantidade de chineses no mundo. 
Esta tirinha foi escolhida por apresentar um sobrenome típico da Argentina, o que exige da aluna/tradutora uma reflexăo funcionalista no momento de traduzir para a língua portuguesa, já que, mantendo o mesmo nome, a tirinha năo teria o mesmo efeito presente no original. Outro ponto que ganha destaque aqui é a interjeiçăo usada por Mafalda ¡Dios mío!. As duas duplas traduziram de maneira diferente nos dois casos, sobrenome e interjeiçăo.
Espanhol
Português
Pérez, Pérez, Pérez .......
(dupla 1) Silva, Silva, Silva...
(dupla 2) Souza, Souza, Souza...
Y hay más, ¡Dios mío!
(dupla 1) E tem mais! Cruzes!
(dupla 2) E tem mais! Meu Deus!

Neste caso, entendemos as duas traduçôes realizadas pelas alunas como sendo funcionalistas, pois levaram em consideraçâo que os sobrenomes "Silva" e "Souza" sâo bem comuns entre os registros de nascimento do povo brasileiro, o que năo acontece com o sobrenome Pérez, que é muito mais recorrente no contexto cultural argentino, como demonstra a própria tirinha da Mafalda. O mesmo podemos considerar quando as alunas optaram pela interjeiçăo "Cruzes" e pela expressăo "Meu Deus", para fazer alusăo a Dio mío, em língua espanhola. As duas opçôes escolhidas pelas alunas sâo frequentes e igualmente aceitas semanticamente pelo público-alvo para demonstrar espanto, surpresa ou terror.

\section{$7^{a}$ ETAPA - APLICAÇĀO DE QUESTIONÁRIO: SEGUNDO MOMENTO DE REFLEXĂO}

A sétima etapa teve como objetivo verificar se houve alguma mudança/ampliaçâo no conceito de traduçâo por parte das alunas após a atividade de traduçâo das tirinhas da Mafalda conjugada com a apresentaçáo da teoria nordiana. As perguntas respondidas pelas estudantes foram as seguintes:

a) - Tras realizar la actividad de traducción de las tiritas de Mafalda, ¿crees que has cambiado de opinión acerca de tu concepto de traducción? Justifica la respuesta. - b) - ¿Crees que trabajar con traducción en la clase de lengua extranjera es una actividad productiva a los estudiantes? ¿Por qué?

Com base nas respostas da primeira pergunta, três estudantes afirmaram que seu conceito de traduçấo mudou, em alguma medida, ao realizar a atividade tradutória, como vemos nos trechos abaixo:

Aluna 1: Sí, traducir las tiritas fué una atividade muy productiva en el sentido de piensar en la traducción de un modo mas amplo e complejo. Analisar las distintas posibilidades para el texto final (meta) sin olvidar el público. 
Aluna 2: Realizar la traducción de las tiritas ayudó para mi pensamiento de lo que es traducción. Que es algo además que la traducción lexical, la sintática, la semântica y el contexto tiene que ser compreendido para hacer una buena traducción, siempre haciendo una adaptación para el público.

Aluna 3: Un poco. Creo que sea más difícil de lo que yo pensaba anteriormente, pues, las expresiones utilizadas en una língua puedo no hacer sentido en la otra, y el traductor tendrá que conocer muy bien la língua de la qual traduce, la língua para la cual vá traducir, el público y donde circula el material traducido.

As três alunas trazem a questăo da dificuldade da traduçăo. Isto pode demonstrar que a tarefa tradutória é mais complexa que a habilidade de compreensáo escrita, pois as estudantes haviam compreendido o sentido das tirinhas, no entanto há uma grande diferença na complexidade da atividade quando a aluna/tradutora tem a tarefa de traduzir uma informaçăo a outro público, diferente do texto base. A traduçăo foi um elemento que possibilitou que os elementos culturais protagonizassem a atividade, oferecendo mais possibilidade de desenvolver a CC das estudantes.

Como podemos observar abaixo, a quarta estudante elaborou uma resposta um pouco diferente das demais colegas:

Aluna 4: No, yo comprendo que traducción es una forma de criar sentido a palabras, frases, expresiones que no comprendemos, cambiando el signo linguístico pero no el sentido.

De acordo com a resposta desta aluna, podemos observar que ela parece năo ter alcançado uma ampliaçâo no seu conceito de traduçăo. Em sua primeira resposta, havia colocado que, em outras palavras, traduzir é dar sentido a uma frase ou expressāo. No questionário final, ainda percebemos que esta aluna continua entendendo a traduçâo de forma bastante limitada, quando usa os vocábulos frases, expresiones e palabras para se referir ao trabalho tradutório. Talvez a proposta de atividade tradutória das tirinhas da Mafalda năo tenha sido suficiente para ampliar os seus horizontes. No entanto, entendemos que a estudante compreende que o sentido supera a letra, isto é, que as questóes semânticas possuem maior importância no processo tradutório, e esta afirmaçấo vai ao encontro da teoria nordiana apresentada.

Sobre a segunda pergunta (b) - ¿Crees que trabajar con traducción en la clase de lengua extranjera es una actividad productiva a los estudiantes? ¿Por qué?), todas as quatro alunas responderam de maneira afirmativa, o que corrobora com a afirmaçáo deste trabalho de que explorar a traduçăo em sala de aula pode ser uma ferramenta de aprendizagem da língua, desde que bem orientada pelo docente. Abaixo destacamos alguns trechos:

Aluna 1: Sí, la traducción hace piensar de una forma diferente para distintas opciones.

Aluna 2: Sí, la actividad de traducción debe ser planeada levando en cuenta los alumnos que van traducir, su nivel en la lengua extranjera, los conocimientos que ellos tienen de expresiones idiomáticas, por ejemplo. 
Aluna 3: Sí. Pues nos permite mostrar a los alumnos las diferencias además de la escrita, hay también la diferencia cultural.

Aluna 4: Sí, creio porque es una actividad que envolve los alumnos a buscar conocimientos de la cultura del pueblo de la lengua extranjera.

Após responderem as peguntas supramencionadas, foi proposto às alunas um momento de discussâo das respostas. Durante o compartilhamento de suas opiniôes, pudemos perceber que as estudantes foram capazes de construir uma ponte entre a teoria de traduçáo nordiana e seus próprios processos tradutórios, evitando a traduçáo palavra por palavra. Acreditamos que este fato se deu muito provavelmente por terem percebido que o destinatário nâo conseguiria interagir da mesma forma como aconteceu com o público argentino das tirinhas originais. Essa pode ter sido uma consequência da consciência funcionalista advinda do conhecimento da teoria apresentada no começo da SD. Ou seja, as alunas tinham uma base teórica de traduçáo, que auxiliou numa prática mais consciente e cada escolha tradutória teve como foco principal o seu destinatário final.

Portanto, à luz da teoria nordiana, podemos intuir que as traduçôes realizadas pelas estudantes podem ser consideradas funcionalistas, já que o leitor final foi colocado em prospecçâo, isto é, sua figura estava permeando todo o processo de traduçăo.

\section{CONSIDERAÇÕES FINAIS}

Através da SD ilustrada neste trabalho, acreditamos que devemos olhar para o ensino de LE como um espaço propício à interaçăo entre alunos e professor, calcado na necessidade dos estudantes e na oportunidade de criaçâo de situaçôes significativas para eles, onde haja oportunidade de comunicaçăo mais próxima ao real.

À luz desta perspectiva, acreditamos na importância de atividades que envolvam a traduçáo dentro da sala de LE sob o olhar funcionalista, no qual se busca trabalhar a língua e seu entorno cultural, enfatizando que língua e cultura estăo intimamente interligadas, ou seja, sâo elementos indissociáveis. Por esta razâo, acreditamos que língua, gênero discursivo e contexto sócio-histórico-cultural sâo elementos que se complementam e que năo devem ser vistos de maneira isolada, segundo a abordagem bakhtiniana. De nada adianta o estudante memorizar, por meio de intermináveis listas, todos os tempos verbais, por exemplo, se nâo souber em quais situaçóes comunicativas reais pode usá-los. Embora seja um conhecimento necessário para o estudante, o aprendizado de uma língua e o desenvolvimento da CC vai muito além das fronteiras gramaticais.

A partir da SD proposta podemos perceber que as alunas foram levadas a refletir sobre todas essas questóes que envolvem o processo tradutório e, sendo assim, tentamos mostrar-lhes que para traduzir e aprender uma LE năo basta apenas ter conhecimentos gramaticais, e sim, é necessário pesquisar e analisar as escolhas linguísticas de acordo com a cultura-meta.

Outro ponto a ser ressaltado através da proposta apresentada é que ela ofereceu às estudantes uma oportunidade de aprofundar os conhecimentos na língua espanhola, através de um trabalho centrado em pesquisa e criatividade, no qual o foco recaiu 
sobre as alunas e em suas necessidades de comunicaçăo. Além disso, esta atividade oportunizou a construçáo coletiva do conhecimento por meio de um diálogo entre a professora e suas alunas. Este diálogo se deu através das negociaçóes de sentido e acomodaçăo do conhecimento prévio das alunas e o novo conhecimento.

Acreditamos que este tipo de atividade em sala de aula pode contribuir de forma significativa para a CC em LE, pois proporciona ao aluno um ambiente desafiador, no qual deve pesquisar sobre a melhor forma de comunicar-se em outra língua. Igualmente o instiga a agir de forma perspicaz, já que deve ter o papel de tradutor, tanto linguístico, como cultural.

Através da aplicaçăo desta SD, observamos que essa forma de trabalhar a traduçâo em sala de aula dá margem a diferentes pontos de vista, distintos do processo de traduçáo decorrente do enunciado "leia e traduza", que nâo instiga os alunos a uma discussăo prévia do texto antes de traduzi-lo e que, muitas vezes, busca apenas uma resposta 'correta' para cada expressăo ou palavra traduzida.

Também podemos perceber que o gênero discursivo funciona como um mediador entre as atividades propostas e a aprendizagem da LE, pois o aluno tem a oportunidade de aprender a dominá-lo, conhecendo melhor suas características para, posteriormente, reconhecê-lo e usá-lo fora da sala de aula. Além disso, o estudante também tem oportunidade de desenvolver outras capacidades linguísticas que pode aplicar a outros gêneros do discurso e ficar frente a situaçôes próximas do real.

O objetivo maior de haver trabalhado com a SD apresentada nasceu a partir de nossa prática docente e observaçâo de diferentes materiais didáticos de LE, que ainda prezam por atividades de traduçăo baseadas no tradicional MGT, limitando a criatividade do estudante e o privando de refletir sobre o próprio estudo da língua (metalinguagem).

A partir de resultados que consideramos positivos, concluímos que a SD pode ser replicada e adaptada a qualquer contexto de ensino/aprendizagem de LE. Além de trabalhar a língua como prática social, a experiência também mostra ao aluno que aprender uma LE é transpor as fronteiras de métodos focados meramente em estruturas gramaticais, percebendo a língua como uma ferramenta real de interaçâo sóciocultural. 


\section{REFERÊNCIAS}

ALBIR, A. H. Traducción y traductología: introducción a la traductodología. Madrid: Edicionaes Cátedra, 2001.

BAKHTIN, M. Marxismo e filosofia da linguagem. Săo Paulo: Ed. Hucitec, 2010a.

Estética da criaçăo verbal. Traduçăo de Paulo Bezerra. 5. ed. Săo Paulo: Editora WMF Martins Fontes, 2010b.

BARROS, D. L. P. de; FIORIN, J. L.(orgs.). Dialogismo, Polifonia e Intertextualidade: em torno de Bakhtin. Sáo Paulo: Editora da Universidade de Sâo Paulo, 2003.

BATALHA, M. C.; JUNIOR, G. P. Traduçâo. Petrópolis, RJ: Vozes, 2007.

CASSANY, D. Describir el escribir. Cómo se aprende a escribir. 17. ed. Madrid: Paidós, 2010.

Taller de textos: leer, escribir y comentar en el aula. Paidós: Buenos Aires, 2008.

CONTERATTO, A. B. B. 0 eu e o outro - partícipes da interaçăo nas práticas de escritura/reescritura, em aulas de língua portuguesa. 2005, 158f. Dissertaçâo (Programa de Pós-Graduaçâo em Linguística). Mestrado em Linguística: Universidade Federal de Santa Catarina, Florianópolis, 2005.

CHOMSKY, N. Reflexōes sobre a linguagem. Lisboa: Ediçōes 70, 1975.

DIAS, S. R. S.; SILVA, M. Dialogia e Interatividade em Educaçăo On-Line. Revista FAEEBA, v. 14, pp. 169-179, 2005. www.abed.org.br/congresso2005/por/pdf/095tcc5. $\operatorname{pdf}(15 / 09 / 2014)$

DOLZ, J; NOVERRAZ, M; SCHNEUWLY, B. Sequências didáticas para o oral e a escrita: apresentaçăo de um procedimento. In SCHNEWLY, B.; DOLZ, J. (Org.). Gêneros orais e escritos na escola. (Traduçâo de Roxane Rojo e Glaís Sales Cordeiro) Campinas, SP: Mercado Aberto, 2004.

HYMES, D. H. On communicative competence. In Pride, J.B.; Holmes, J. Sociolinguistics: selected readings. Harmondsworth: Penguin, 1972.

MARTINS, J. C. Vygotsky e o Papel das Interaçôes Sociais na Sala de Aula: Reconhecer e Desvendar o Mundo. Série Ideias n. 28. Sâo Paulo: FDE, 1997.

NORD, C. Texto Base-Texto Meta: Un modelo funcional de análisis pretraslativo. Universitat Jaume I. Servei de Comunicació i Publicacions, 2010.

OLIVEIRA, L. A. O conceito de competência no ensino de línguas estrangeiras. Sitientibus, Feira de Santana, n. 37, pp. 61-74, jul./dez. 2007.

PAGANO, A. Crenças sobre a traduçăo e o tradutor. In: Traduzir com autonomia: estratégias para o tradutor em formaçáo. Sáo Paulo: Contexto, 2000, pp. 9-26.

PETTER, M. Linguagem, língua, linguística. In FIORIN, J. L. Introduçăo à linguística (Org). Săo Paulo: Contexto, 2011.

QUINO, J.S.L. Toda Mafalda. Ediciones de La Flor: Buenos Aires, 2007. 
Toda Mafalda. Ediciones de La Flor: Buenos Aires, 2010.

SALDANHA, C. T. Interaçâo nos fóruns de discussâo: uma análise linguística. Dissertaçâo de Mestrado em Educaçăo, Universidade Federal de Santa Catarina, Florianópolis, 2011. SEARA, I. C; NUNES, V. G. Metodologia de ensino do espanhol. Florianópolis: LLE/CCE/ UFSC, 2010.

VYGOTSKY, L. S. Pensamento e Linguagem. Săo Paulo: Martins Fontes, 1998. 